failure has been moulded by bureaucratic constraints, so that it is different in both scale and strategy from those in other relatively prosperous countries. It is also slow to respond to medical advances, which may need extra resources to make them equally available to all who could benefit, such as recombinant human erythropoietin for patients undergoing dialysis. Will the new methods of NHS funding to be introduced in 1991 change the pattern of the programme? Money that follows patients is said to make bureaucratic logjams simpler to resolve ${ }^{20}$ and it could provide an incentive for opening new renal units. The wishes of patients and the costs of transporting them to thrice weekly treatments both point to the desirability of increasing the numbers of renal units and specialists to fill geographical gaps in provision. McGeown and Feest et al have documented the real need for dialysis and transplantation. The reasons why the old style NHS has fallen short are known. Is it too much to hope that the white paper holds the key to open doors that have been held shut for too long?

A J WING

Consultant Physician

United Medical and Dental School,

St Thomas's Hospital,

London SE1 7EH

I McGeown MG. Chronic renal failure in Northern Ireland 1968-70. Lancet 1972;i:307-10

2 Pendreight DM, Heasman MA, Howitt LF, et al. Survey of chronic renal failure in Scotland. Lancet 1972;i:304-7

3 Branch RA, Clarke GW, Cochrane AL, Jones JH, Scarborough H. Incidence of uraemia and requirements for maintenance haemodialysis. Br Med f $1971 ;$; :249-54

4 Challah S, Wing AJ, Bauer R, Morris RW, Schroeder SA. Negative selection of patients for dialysis and transplantation in the United Kingdom. BrMed f 1984;288:1119-22.

5 Patton J. Kidney patients. House of Commons Official Report (Hansard) 1984 Dec 20;710:cols $309-10$

6 Edwards N. Kidney patients. House of Commons Official Report (Hansard) 1984 Dec 5;710:col 23

Wing AJ, Broyer M, Brunner FP, et al. Demography of dialysis and transplantation in Europe in 1985 and 1986: trends over the previous decade. Nephrol Dial Transplant 1988;3:714-27.

8 Rennie D, Rettig RA, Wing AJ. Limited resources and the treatment of end stage renal failure in Britain and the United States. Qf Med 1985;56:321-36.

9 McGeown MG. The prevalence of advanced renal failure in Northern Ireland. $\mathrm{Br}$ Med $\mathcal{f}$ 1990;301:900-3.

10 Feest TG, Mistry CD, Grimes DS, Mallick NP. Incidence of advanced chronic renal failure in the United Kingdom and the need for end stage renal replacement treatment. $\mathrm{Br}$ Med $\mathrm{J}$ 1990;301:897-900.

11 Joint Working Party. Treatment of and mortality from diabetic renal failure in patients identified in the 1985 United Kingdom survey. Br Med f 1989;299:1135-6.

12 Bergstrom J, Alverstrand A, Bucht $\mathrm{H}$, Gutierrex A. Progression of chronic renal failure in man is retarded with more frequent clinical follow-up and better blood presssure control. Clin Nephrol 1986;25:1-6.

13 Wing AJ. Why don't the British treat more patients with kidney failure? BrMed $\mathcal{F} 1983 ; 287: 1157-8$

14 Dalziel $M$, Garrett $C$. Intraregional variation in treating end stage renal failure. Br Med $\mathcal{J}$ 1987;294:1382-3.

15 Smith WGJ, Cohan DR, Asscher AW. Evaluation of renal services in Wales with particular reference to the role of subsidiary renal units; report to the Welsh office 1989. Cardiff: KRUF Institute of Renal Disease, Royal Infirmary, 1989.

16 Feest TG, Riad HN, Collins CH, Golby MGS, Nicholls AJ, Hamad SN. Protocol for increasing organ donation after cardiovascular deaths in a district general hospital. Lancet 1990;335:1133-5. Department of Health. Special health authority to manage UK Transplant Service. London:DoH, 1990. (Press release, 11 th June 1990.) 18 Halper T. The misfortunes of others: end stage renal disease in the United Kingdom. Cambridge:

9 Wood IT, Mallick NP, Wing AJ. Prediction of resources needed to achieve the national target for the treatment of renal failure. Br Med $\mathcal{F}$ 1987;294:1467-70.

20 Dorrell S. Kidney patients. House of Commons Official Report (Hansard) 1990 May 24;173:cols $434-42$

\section{The pelvic ileal reservoir: apocalypse later?}

\section{Patients need monitoring for the long term effects of reservoir construction}

The construction of a pelvic ileal reservoir with ileoanal anastomosis was first proposed as an alternative to permanent ileostomy and continent ileostomy in patients undergoing proctocolectomy for ulcerative colitis.' ${ }^{\prime}$ Ulcerative colitis remains the most common indication, but the operation has also become an effective alternative to total colectomy and ileorectal anastomosis for familial adenomatous polyposis and has been used in patients with functional bowel disorders such as chronic megacolon and idiopathic constipation. The procedure is now considered a safe and satisfactory alternative to permanent ileostomy ${ }^{2}$ : most suitable patients accept the offer of a pelvic reservoir rather than a.permanent ileostomy. ${ }^{3}$

Even so, the creation of the reservoir is not without complications. The altered intraluminal environment in the reservoir has a profound effect on the ileal mucosa, producing chronic inflammation and varying degrees of villous atrophy. ${ }^{+}$ These inflammatory and architectural changes result in an appearance of colonic metaplasia. ${ }^{+5}$ The evidence for colonic metaplasia is further substantiated by histochemical studies of mucin $^{+}$and by the acquisition of immunoreactivity for putative colon specific monoclonal antibodies. ${ }^{67}$ The inflammatory and metaplastic alterations occur in the reservoirs of patients with both ulcerative colitis and familial adenomatous polyposis and probably represent an adaptive response of the mucosa to the altered intraluminal environment. The ileal mucosa of experimental animal models shows similar metaplastic changes after reservoir construction. ${ }^{89}$

One of the more severe long term complications of the reservoir is the active chronic inflammatory condition known as pouchitis. There is much confusion and controversy surrounding pouchitis, mainly because the term has not been tightly defined. ${ }^{10}$ Several heterogeneous mechanisms, including mucosal ischaemia, ${ }^{7112}$ mucosal prolapse, ${ }^{+}$and Crohn's disease ${ }^{11}$ may cause inflammation in the reservoir, and all have been called pouchitis. This confusion accounts for the large divergence in prevalence rates in large series$7 \%$ to $42 \% .^{10}$ The definition of pouchitis should include clinical (painful increase in stool frequency, urgency, systemic symptoms), endoscopic (increased vascularity, bleeding, ulceration), and histopathological (acute inflammation, ulceration, chronic changes) criteria. ${ }^{11}{ }^{12}$ These criteria define a condition that occurs in about $10-20 \%$ of patients with ileal reservoirs. ${ }^{11} 1{ }^{14}$ Clinically, this syndrome is a relapsing and remitting chronic disease with a variable but often favourable response to antibiotics (particularly metronidazole) and to sulphasalazine or steroids, or both. Despite the undoubted response of many patients with pouchitis to metronidazole no consistent bacteriological changes have been observed in the reservoirs of these patients ${ }^{51+16}$ : the response to metronidazole may relate to its immunosuppressive properties. Stasis and bacteriological changes are probably a prerequisite for the morphological changes in the mucosa of the reservoir, and pouchitis may then supervene in susceptible individuals.

Although the cause of pouchitis is obscure, it seems to be closely linked to ulcerative colitis. Similar associations have been observed in the ileitis that complicates continent ileostomy reservoirs. ${ }^{11} 17$ In most large series pouchitis, when adequately defined, is more common in patients with ulcerative colitis than in those with familial adenomatous polyposis, ${ }^{1011}$ and indeed may well be restricted to them. Acute inflammation in the reservoir mucosa, with and without pouchitis, is much more prevalent in patients with ulcerative colitis than in those with familial adenomatous polyposis, ${ }^{+18}$ and similar distributions of immunoglobulin subtypes within intramucosal plasma cells have been shown in the reservoir of patients with pouchitis as in the colonic mucosa of patients with colitis. ${ }^{19}$ In both pelvic reservoirs and continent ileostomies pouchitis is associated with the development of conditions such as arthritis, iridocyclitis, and pyoderma gangrenosa, which are characteristic extracolonic manifestations of idiopathic inflammatory bowel disease. ${ }^{2021}$ Patients with extensive colitis at proctocolectomy are more likely to develop pouchitis than those with more restricted disease, ${ }^{22}$ although there is no relation between backwash ileitis and pouchitis. ${ }^{23}$ 
An attractive hypothesis for the pathogenesis of pouchitis is that the pelvic reservoir undergoes a process of colonic metaplasia, possibly as a result of changes in bacterial flora, and that this metaplasia recreates a colon-like environment that favours the recurrence of ulcerative colitis in the ileal reservoir. More worrying perhaps are the long term implications of colonic metaplasia in the reservoir mucosa. The mucosal epithelium of the reservoir shows increased proliferative activity in patients with and without pouchitis. ${ }^{6}$ The coexistence of colonic metaplasia and hyperproliferaton may increase the neoplastic potential of the reservoir's epithelium. In both ulcerative colitis and familial adenomatous polyposis the colonic mucosa shows hyperproliferation, ${ }^{2425}$ and, although to different degrees, both conditions are associated with epithelial dysplasia and malignancy.

The clinical, pathological, and experimental evidence should be put into context before any conclusions are drawn about the long term outlook for patients with pelvic ileal reservoirs. Current evidence suggests that the neoplastic potential of the pelvic reservoir is low. No convincing cases of epithelial dysplasia have been described in reservoirs constructed for ulcerative colitis. Very few reservoirs have been in place for over 10 years, however, and nearly all cases of epithelial dysplasia in the colon and rectum associated with ulcerative colitis arise after this time. Little evidence exists for increased neoplastic risk in continent abdominal ileostomies, some of which have been in place for 20 years. ${ }^{17} \mathrm{~A}$ recent report describes a carcinoma arising in a pelvic reservoir of a patient with colitis; in the authors' view the carcinoma arose not from metaplastic ileal mucosa but from remaining rectal mucosa within the pouch. ${ }^{26}$ In patients with familial adenomatous polyposis adenomas have been observed in both pelvic reservoirs and continent abdominal ileostomies, ${ }^{42728}$ but such adenomas could be considered to be part of the normal range of disease in familial adenomatous polyposis.

The optimist's view of the pelvic reservoir is that there is no increased neoplastic potential and that pouchitis is merely a hiccup in the establishment of the operation as the panacea for all diffuse colonic mucosal disease. The pessimist would suggest that all patients with an original diagnosis of ulcerative colitis will eventually develop pouchitis, that some will develop dysplasia and carcinoma, and that many patients with familial adenomatous polyposis will develop adenomatous dysplasia in the reservoir mucosa with high rates of malignancy. The truth, of course, lies somewhere in between. Until we have more objective evidence of the long term consequences of ileal reservoir construction surveillance by endoscopy and mucosal biopsy is warranted.

Consultant Histopathologist,

NEIL A SHEPHERD

Gloucestershire Royal Hospital,

Gloucester GL1 3NN

\footnotetext{
1 Parks AG, Nicholls RJ. Proctocolectomy without ileostomy for ulcerative colitis. $\mathrm{Br}$ Med $\mathcal{f}$ 1978;ii:85-8.

2 Pemberton JH, Kelly KA, Beart RW, Dozois RR, Wolff BG, Ilstrup DM. Ileal pouch-anal anastomosis for chronic ulcerative colitis. Long-term results. Ann Surg 1987;206:504-13.

3 Mortensen N. Progress with the pouch-restorative proctocolectomy for ulcerative colitis. Gut 1988;29:561-5.

4 Shepherd NA, Jass JR, Duval I, Moskowitz RL, Nicholls RJ, Morson BC. Restorative proctocolectomy with ileal reservoir - pathological and histochemical study of mucosal biopsy specimens. J Clin Pathol 1987;40:601-7.

5 O'Connell PR, Rankin DR, Weiland LH, Kelly KA. Enteric bacteriology, absorption, morphology and emptying after ileal pouch-anal anastomosis. Br f Surg 1986;73:909-14.

6 De Silva HJ, Millard PR, Kettlewell M, Mortensen NJ, Prince C, Jewell DP. Mucosal haracteristics of pelvic ileal pouches. Gut (in press).

7 Shepherd NA. The pelvic ileal reservoir: pathology and pouchitis. Neth $\mathcal{Y}$ Med (in press)

8 Luukonen P, Jarvinen H, Lehtola A, Sipponen P. Mucosal alterations in pelvic ileal reservoirs. A histological and ultrastructural evaluation in an experimental model. Ann Chir Gynaecol 1988;77:91-6.

9 O'Byrne JM, O'Connell PR, Nolan N, Marks P, Tanner WA, Keane FBV. Colonic metaplasia of ileal mucosa: an experimental model. Gut 1989;30:1477.

10 Dozois RR, Goldberg SM, Rothenberger DA, et al. Symposium: restorative proctocolectomy with ileal reservoir. Int $\mathcal{f}$ Color Dis 1986;1:2-19.

11 Shepherd NA, Hulten L, Tytgat GNJ, et al. Workshop: pouchitis. In f Color Dis 1989;4:205-29.

12 Hosie K, Sachaguchi M, Tudor R, Gourevitch D, Kmiot W, Keighley MRB. Pouchitis following proctocolectomy is associated with mucosal ischaemia. Gut 1989;30:1471-2.
}

13 Madden MV, Farthing MJG, Nicholls RJ. Inflammation in ileal reservoirs: pouchitis. Gut 1990;31:247-9.

14 Nicholls RJ, Belliveau P, Neill M, Wilks M, Tabaqchali S. Restorative proctocolectomy with ileal reservoir: a pathophysiological assessment. Gut 1981;22:461-8.

15 Luukonen P, Valtonen V, Sivonen A, Sipponen P, Jarvinen H. Fecal bacteriology and reservoir ileitis in patients operated on for ulcerative colitis. Dis Colon Rectum 1988;31:864-7.

16 Nasmyth DG, Godwin PGR, Dixon MF, Williams NS, Johnston D. Ileal ecology after pouch-ana anastomosis or ileostomy. A study of mucosal morphology, fecal bacteriology, fecal volatile fatty acids and their interrelationship. Gastroenterology 1989;96:817-24.

17 Hulten L, Svaninger G. Facts about the Kock continent ileostomy. Dis Colon Rectum 1984;27:553-

8 Moskowitz RL, Shepherd NA, Nicholls RJ. An assessment of inflammation in the reservoir after restorative proctocolectomy with ileoanal ileal reservoir. Int $\mathcal{F}$ Color Dis 1986;1:167-74.

9 Meuwissen SGM, Hoitsma H, Boot H, Seldenrijk CA. Pouchitis (pouch ileitis). Neth $\mathcal{F}$ Med 1989;35(suppl):54-6.

20 Knobler H, Ligumsky M, Okon E, Ayalon A, Nesher R, Rachmilewitz D. Pouch ileitisrecurrence of the inflammatory bowel disease in the ileal reservoir. Am $\mathcal{f}$ Gastroenterol 1986;81:199-201.

i) Tytgat GNJ, Deventer SJH. Pouchitis. Int f Color Dis 1988;3:226-8.

22 Farrands PA, Shepherd NA, Nicholls RJ. Ileal reservoir inflammation (pouchitis) after restorative proctocolectomy ileal reservoir. Gut 1988;29:1486.

23 Gustavsson S, Weiland LH, Kelly KA. Relationship of backwash ileitis to ileal pouchitis after ileal pouch-anal anastomosis. Dis Colon Rectum 1987;30:25-8.

24 Allan A, Bristol JB, Williamson RCN. Crypt cell production rate in ulcerative proctocolitis: differential increments in remission and relapse. Gut 1985;26:999-1003.

25 Deschner EE, Lipkin M. Proliferative patterns in colonic mucosa in familial polyposis. Cancer 1975;35:413-8.

26 Stern H, Walfisch S, Mullen B, McLeod R, Cohen Z. Cancer in an ileoanal reservoir: a new late complication? Gut 1990;31:473-5.

27 Beart RW, Fleming CR, Banks PM. Tubulovillous adenomas in a continent ileostomy after proctocolectomy for familial polyposis. Dig Dis Sci 1982;27:553-6.

28 Stryker SJ, Kent TH, Dozois RR. Multiple adenomatous polyps arising in a continent reservoir ileostomy. Int f Color Dis 1987;2:43-5.

\section{National Cervical Screening Programme}

\section{Enforcement and coordination are required: guidance and interpretation are not enough}

In the mid-1980s defects in the programme of screening for cervical cancer in Britain were highlighted in a series of research reports and in press, television, and radio programmes. Deaths were occurring that should have been prevented; women had to wait for months for the results of their tests, others were not recalled when they should have been, and many women were still not being screened at all. ${ }^{12}$

These deficiencies led to a reappraisal of the NHS programme, and in 1988 the Department of Health issued a guidance circular intended to improve standards. ${ }^{3}$ Shortly afterwards the National Association of Health Authorities looked at the results being achieved and concluded that "there is every reason to believe that the NHS has risen to the challenge of translating policy into reality." 4 The department should be congratulated for now (perhaps bravely) commissioning an independent audit ( $p$ 915) of the performance of district health authorities. ${ }^{5}$

Some of the findings certainly suggest that all is well. All districts now have computerised call-recall programmes, and 93\% have fail safe mechanisms to follow up abnormal smears. An average smear reporting time of less than four weeks in three quarters of districts is a result likely to receive favourable publicity-although the new general practitioner contract, aiming at achieving $80 \%$ target coverage, has recently substantially increased this time. ${ }^{5}$ Three quarters of the districts were "fairly satisfied" with their programme; but, interestingly enough, this was not assessed by the prime performance indicator of effectiveness (not evaluated by Elkind et al) but simply reflected the hard work and commitment of those concerned.

The report should, however, cause some disquiet as well as some satisfaction. Substantial variability was found among districts. Some findings, such as restricted choice of smear taker and non-notification of results, are important causes of distress to women. Others warrant urgent explanation. Why, 